総 説

\title{
医薬研究におけるメタアナリシスと公表バイアス Meta-analysis and Publication Bias in Medical Research
}

\author{
浜田知久馬 $* 1$. 中西豊支 $* 2$ ・松岡伸篤 $* 3$ \\ Chikuma Hamada*1, Yushi Nakanishi ${ }^{* 2}$ and Nobushige Matsuoka*3 \\ ${ }^{* 1}$ 東京理科大学 工学部 経営工学科 \\ $* 2$ 興和株式会社 医薬事業部臨床解析部 統計解析課 \\ *3ファイザー株式会社 臨床開発部門統計・解析部 \\ ${ }^{* 1}$ Department of Management Science, \\ Faculty of Engineering, Tokyo University of Science \\ ${ }^{* 2}$ Statistical Analysis Section, \\ Biostatistical and Data Management Department, \\ Pharmaceutical Development Department, Kowa Co., Ltd. \\ ${ }^{* 3}$ Pfizer Global R \& D, Tokyo Laboratories, \\ Statistical and Clinical Programming, Pfizer Japan Inc. \\ e-mail:hamada@ms.kagu.tus.ac.jp
}

\begin{abstract}
Meta-analysis is defined to be 'the statistical analysis of a large collection of analysis results from individual studies for the purpose of integrating the findings'. Since the 1980s there has been an upsurge in the application of meta-analysis to medical research. The rapid increase in the number of meta-analysis being conducted during the last decade is mainly due to a greater emphasis on evidence based medicine and the need for reliable summaries of the vast and expanding volume of clinical studies. Over the same period there have been great developments and refinements of the associated methodology of meta-analysis. When judging the reliability of the results of a meta-analysis, attention should be focused on 'publication bias'. Publication bias is the term for what occurs whenever the research that appears in the published literature is systematically unrepresentative of the population of completed studies. This bias can provide a flaw of the result of meta-analysis. In this article, the causes and origins of publication bias are reviewed, and then the history and some findings of publication bias in medical research are presented. Several statistical methods that have been developed to detect, quantify and assess the impact of publication bias in meta-analysis are demonstrated.
\end{abstract}

Key words: meta-analysis; publication bias; funnel plot; failsafe number; selection model; trim and fill method.

Received August 2006. Revised September 2006. Accepted October 2006. 


\section{1. メタアナリシスの歴史と現状}

系統的レビュー (systematic review) とは従来の総説論文 (review) に似ているが，光の過程を 系統的に行なったものである.すなわち参考にした論文の収集法を明確にし，光れらの論文の評価 法を明示し，個々の論文の結果を総合的に評価するための方法を示し，客観的に行なった総説が系 統的レビューである (Chalmers and Altman (1995)) . したがって従来の総説よりテーマが明確で あることが多い，一方，メタアナリシス (meta-analysis) をタイトルにつけた研究論文も最近で は珍しくなくなってきた . 広い意味では系統的レビューもメタアナリシスに入れることができる . 狭い意味で言うと，系統的レビューの一部分，すなわち個々の論文の結果を統合するための統計解 析がメタアナリシスである (折笠 (2003)) .メタアナリシスという用語は , "primary-analysis" , “secondary-analysis", “meta-analysis”という流れで登場した . 簡単に言えば，いくつかの類似 した研究を併合して, 総合的な評価を下すための方法論である. 各研究の解析結果をもう一度解 析するので, “analysis of analysis”ともいえる (Glass (1976)) . 歴史的には医学分野への応用は， 欧米を中心に 1980 年代より数多くなされはじめ , メタアナリシスの総説論文を Simon (1987a, b) がまとめ, 早期乳癌の治療に対するタモキシフェンの有効性をメタアナリシスによって評価し たことによって一躍有名になった（Early Breast Cancer Trialists Collaborative Group (1992)) . またメタアナリシスを組織的，継続的に行うための組織として英国のコクランセンターが 1993 年に開設され, 大腸癌の治療法 , 抗血小板療法 , 線溶療法等については, 既にメタアナリシスの 結果が公表されている. 全世界の研究者がデータを持ち寄って , 分担・共同作業を行う.しかも 重要なことは, コクランセンターでは, これらの総合評価の結果を時代とともに更新する体制を とっている点である (津谷 (1997)) . コクランセンターの行ったメタアナリシスの結果について は , コクランライブラリーとして http://www.update-software.com/cochrane から入手可能であ る，また CD としても入手可能である .

医学分野では, 最近メタアナリスの数が爆発的に増大している. Lau et al. (1998) は 1970 年代 にはわずか 16 のメタアナリシスが発表されたに過ぎなかったのが , 1980 年代には 279,1990 年 から 1992 年にかけては 134,1996 年だけで 500 以上が発表されていることを報告している.著 者達が医薬文献の最大のデータベース Medline で'meta-analysis’をキーワードとして検索した結 果，1996では 833 件だったものが 10 年後の 2005 年には 3116 件と 4 倍弱に増加していた . キー ワードに 'meta-analysis' という単語を含んでいる論文を検索したので, メタアナリシスについて の方法論的論文も含まれているが , メタアナリシスに関する関心が医学分野で高まっているのは 疑いのないところである.EBM (Evidence Based Medicine) の流れの中で, 現在では複数の無作 為化臨床試験のメタアナリスが , 科学的証拠能力が最も高いとされている (Sackett et al. (2000), The American Society of Clinical Oncology (1997)) .

医学研究におけるメタアナリシスの意義は, 1 つの医学上の問題に対し独立に複数行われた研 究を統計学的に併合することによって, サンプルサイズの制約のため単独の研究では立証しにく い以下の問題に答えることである (Whitehead (2002)) .

1）治療効果についてより精度の高い推定值を得る。

2) あらかじめ設定したサブグループでの治療効果を評価する . 


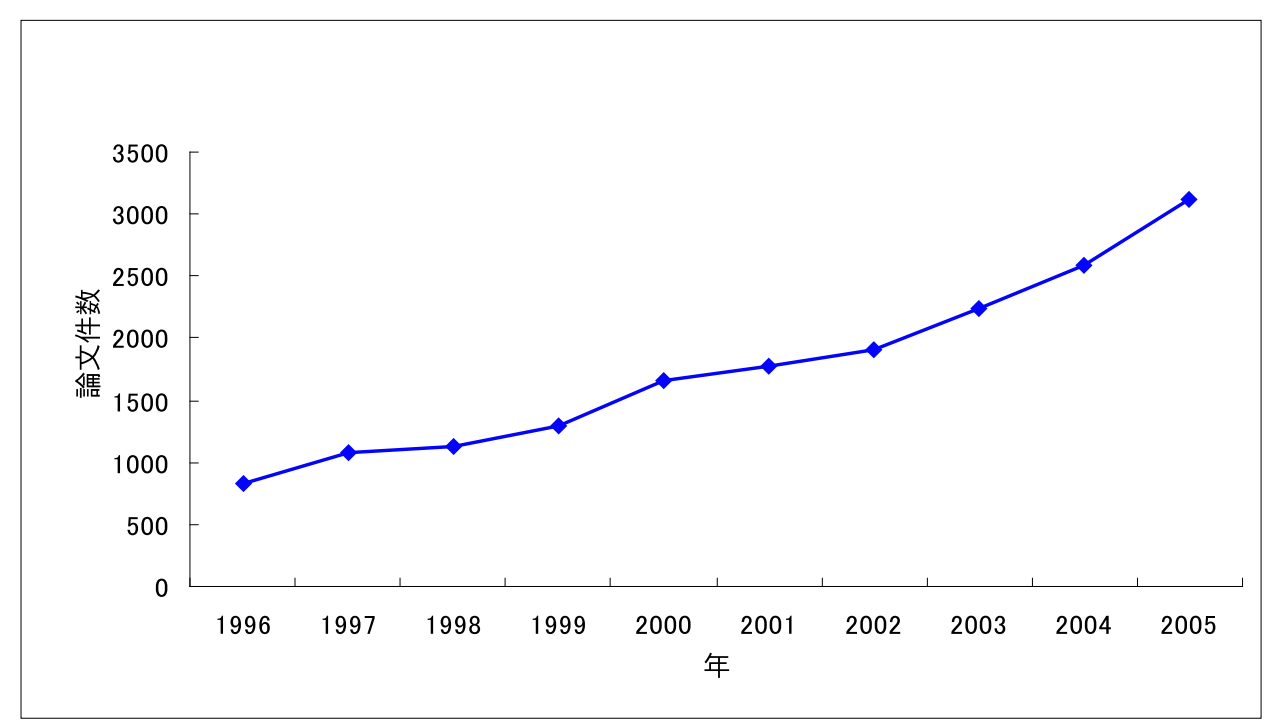

図 1.メタアナリシスをキーワードとした医学論文数の経年変化

3) 個別の研究では検出力が不十分である副次的な評価指標について効果を評価する .

4) 特定のサブグループにおける安全性あるいは, 頻度の少ない稀な副作用発現率を精度高く 評価する .

5) 効果の研究間の変動について評価することによって, 効果の一般化可能性について検討する . 通常単独の無作為化臨床研究で有意な結果が出たとしても，厳密な患者の適格基準・除外基準 を設けるため，対象患者集団は狭く，また薬斉の投与方法も厳密に規定されるので，広い集団に ついて，投与条件が多少異なったときに結果が再現できるかは判断できない．これに対してメタ アナリシスでは複数の研究を収集するので, 対象患者の適格基準や，投与方法は研究ごとに異な ることになる．このとき複数の研究で, 薬斉効果か類似していれば, 多少条件が変わっても結果 は再現性があり，一般化可能性が示唆されることになる．これに対して研究間変動が大きい場合 は，全体で有意であっても，患者層や投与条件が異なると効果の大きさが異なってくるので，一 般化して広い集団について同樣の治療効果を再現できると結論付けることはできない，研究間で 効果の異質性が大きい場合に, 特に効果の強い研究グループ・条件を特定できれば, 臨床上の新 たな仮説を提示し, テーラーメード医療につながる重要な情報が得られる可能性もある．

本稿ではメタアナリスを理解する上で最低限必要な数理について 2 節で述へ , 3 節ではメタア ナリシスを行う上の, 非常に重要な問題である公表バイアスの分類と現状について触れ，4節で 公表バイアスに対する方法論の歴史と現在までの研究結果について報告し，5節では公表バイア スに関する展望について述べる． 
2. メタアナリシスの数理

メタアナリシスで統合効果を推定するためのアプローチは, 大きく 2 つに分類できる . 固定効 果モデル (fixed-effect model) と変量効果モデル (random-effect model) である. 前者は, 各研 究で真の効果の大きさは等しく，研究間で効果の推定值が異なるのは誤差的変動によるとみなす． 後者は, 研究間で真の効果の大きさはある值を中心にして分布すると考える .

1) 固定効果モデル (fixed-effect model)

$K$ 個の研究結果を統合する場合で説明する .

各研究で, 2 群の平均值の差, オッズ比, ハザード比などの効果の推定值が得られており，これ を $M_{k}(k=1,2, \cdots, K)$ と表すことにする (オッズ比 , ハザード比は通常対数変換してから効果を 統合する) . 本稿では $E\left[M_{k}\right]=0$ のとき効果がなく，帰無仮説が成立することを想定する.$K$ 個 の効果指標を統合するための素朴なアイデアは， $M_{k}$ の算術平均を計算することである. 各研究 で症例数が大きく異ならないときは, このアイデアはとれほど悪くはないが, 研究間で症例数が 大きく違い, 推定精度が異なる場合は, 単純な算術平均ではなく, 推定精度が高い研究には大き な重みを与え，低い研究には小さな重みを与える重み付き平均を計算する方が合理的である．各 研究に与える重みを $W_{k}$ とすると，重み付き平均 $M$ は (1) 式で表すことができる .

$$
M=\frac{\sum_{k=1}^{K} W_{k} \cdot M_{k}}{\sum_{k=1}^{K} W_{k}}
$$

この重み付き平均が固定効果モデルでのメタアナリシスで推定する統合効果 $M$ となる .

問題はどのような重み $W_{k}$ を与えるかであるが , 一般には $M_{k}$ の分散 $V_{k}$ の逆数に比例するよ うに $W_{k}$ を定めると，統合効果の分散が $\Sigma W_{k}$ 一定の下で最小になる．もし研究間で誤差的変動 の大きさが等しく，等分散性が成り立てば, $M_{k}$ の分散は, 各研究の症例数 $n_{k}$ の逆数に比例する ので, $W_{k}$ は症例数 $n_{k}$ そのものに設定すればよい .

$W_{k}$ を $1 / V_{k}$ とした場合，統合効果の分散 $V[M]$ は簡単な数式演算により (2) 式のようになるこ とが示される .

$$
V[M]=\frac{1}{\sum_{k=1}^{K} W_{k}}=\frac{1}{\sum_{k=1}^{K} \frac{1}{V_{k}}}
$$

$V_{k}$ の小さな研究を収集する，または多くの研究を集めると $V[M]$ の分母 $\Sigma W_{k}$ が大きくなるので， $V[M]$ が小さく精度の高い推定を行なうことができる .これがメタアナリシスの利点である .

$M$ と $V[M]$ から統合効果の有意性検定の $Z$ 統計量を導き，また $M$ の信頼区間を構成すること ができる .

$$
Z=\frac{M}{\sqrt{V[M]}}, \quad 95 \% \mathrm{CI}: M \pm \mathrm{z}_{\alpha / 2} \sqrt{V[M]}=M \pm \mathrm{z}_{\alpha / 2} \sqrt{\frac{1}{\sum_{k=1}^{K} W_{k}}}
$$


正規近似を行なう場合， $Z$ 統計量を，正規分布の \%点と比較することによって検定を行なうこ とができる．また $z_{\alpha / 2}$ は正規分布の上側 $\alpha / 2 \%$ 点である．両側 $95 \%$ 信頼区間を構成したい場合 は，正規分布の上側 $2.5 \%$ 点である 1.96 を用いればよい .

研究ごとに, 効果の大きさ $M_{k}$ の 2 乗を炎の分散 $V_{k}$ で割ると, 帰無仮説の下で自由度 1 の力 イ 2 乗分布にしたがう統計量 $\chi_{k}^{2}$ が構成できる.$K$ 個の独立な研究について $\chi_{k}^{2}$ を足し合わせる と, 完全帰無仮説 $\left(E\left[M_{k}\right]=0(k=1,2, \cdots, K)\right)$ の下で, 自由度 $K$ のカイ 2 乗分布にしたがう統 計量 $\chi^{2}$ が導ける . この $\chi^{2}$ は次のように分解することができる .

$$
\chi^{2}=\sum_{k=1}^{K} \chi_{k}^{2}=\sum_{k=1}^{K} \frac{M_{k}^{2}}{V_{k}}=\sum_{k=1}^{K} \frac{M^{2}}{V_{k}}+\sum_{k=1}^{K} \frac{\left(M_{k}-M\right)^{2}}{V_{k}}=Z^{2}+Q
$$

すなわち，全体の $\chi^{2}$ は, 重み付き平均 $M$ の 0 からの隔たりを測る $Z$ 統計量の 2 乗と, 重み付 き平均から個々の効果指標のズレを計る統計量 $Q$ に分解できる.$Q$ 統計量は (5) 式のようにも表 すこともできる .

$$
Q=\sum_{k=1}^{K} W_{k}\left(M_{k}-M\right)^{2}
$$

完全帰無仮説の下で $\chi^{2}, Q, Z^{2}$ は光れ光れ自由度 $K, K-1,1$ のカイ 2 乗分布にしたがう. 研 究間で真の効果が均一であるかは, $Q$ を自由度 $K-1$ の力イ 2 乗分布と比べることで検定を行う ことができる．ただし $Q$ 統計量に基づく異質性の検定は一般に検出力が低いことに注意する必要 がある . 次に固定効果のメタアナリシスの適用例を示す .

Hackshaw (1997) は受動喫煙と肺癌の関係を評価した 37 研究について，メタアナリシスを行っ た . 34 個のケース・コントロール研究と 3 個のコホート研究から構成され, 前者はオッズ比, 後 者は相対リスクを指標として統合効果を計算した . 本稿では, オッズ比と相対リスクを合わせて， リスク比とよぶことにする . 異なった研究デザインの結果得られたリスク比を統合することには 議論があるが , 本稿ではメタアナリシスの例題としてこのデータを用いる .このデータについて は http://www.meta-analysis.com/で入手可能である . 正規近似がよくなるようにリスク比を対 数変換してから統合効果を計算すると $M=0.215$ となり，95\%信頼区間は $0.122 \sim 0.307$ となる. 元のスケールに戻すと，リスク比と光の $95 \%$ の信頼区間は $1.24(1.13 \sim 1.36)$ となり，光れほど 強い効果ではないが, 受動喫煙によって肺癌のリスクが増大することがわかる $. Z=4.56$ で統合 効果は $p<0.00001$ と高度に有意であり，また研究間の効果の均一性の $Q$ 統計量は 47.52 で, 自 由度 36 のカイ 2 乗分布と比較すると, $p=0.09$ と $5 \%$ 水準で有意ではないが, 弱い研究間変動が 存在することがわかる .

固定効果モデルでは効果の大きさの推定值 $M_{k}$ の分布が $N\left(\mu, V_{k}\right)$ の正規分布にしたがうことを 想定している．研究間の効果の大きさの違いは推定誤差の範囲で生じ，真值は $\mu$ に等しいとする モデルである .

2) 変量効果モデル (random-effect model)

変量効果モデルでは, 各研究の真の効果 $E\left[M_{k}\right]$ が期待值 $\mu$, 分散 $\tau^{2}$ の正規分布 $N\left(\mu \tau^{2}\right)$ にし たがっていることを仮定する .このとき効果の大きさの推定値 $M_{k}$ の分布は $N\left(\mu, V_{k}+\tau^{2}\right)$ となる . 
研究間分散 $\tau^{2}$ を推定するには最尤法などの方法もあるが，反復計算が必要であり，モーメント 法によって推定するのが簡便である .この方法では前述の研究間の効果の均一性を評価する $Q$ 統 計量を利用して， $\tau^{2}$ を次のように推定する。

$$
\widehat{\tau}^{2}=\frac{Q-(K-1)}{\sum_{k=1}^{K} W_{k}-\frac{\sum_{k=1}^{K} W_{k}^{2}}{\sum_{k=1}^{K} W_{k}}}
$$

$Q$ は帰無仮説 $H_{0}: E\left[M_{1}\right]=E\left[M_{2}\right]=\cdots=E\left[M_{K}\right]$ の下では, 自由度 $K-1$ のカイ 2 乗分布にし たがい, この分布の期待值は $K-1$ である .この期待值よりも $Q$ が大きい場合は, 研究間変動が 存在することを意味するので $\tau^{2}$ の推定值は正の值をとる $Q Q$ が $K-1$ を下回る場合は,$\tau^{2}$ の推 定值は負の值となるがこの場合には 0 で置き換える .この方法は考案者にちなんで, DerSimonian and Laird 法とよばれる (DerSimonian and Laird (1986)).$\tau^{2}$ の推定值が求まると, 変量効果 モデルに基づいた統合効果 $M_{R}$ は (7) 式のように推定される .

$$
\begin{array}{r}
M_{R}=\frac{\sum_{k=1}^{K} \frac{M_{k}}{V_{k}+\widehat{\tau}^{2}}}{\sum_{k=1}^{K} \frac{1}{V_{k}+\widehat{\tau}^{2}}}=\frac{\sum_{k=1}^{K} W_{k}^{*} M_{k}}{\sum_{k=1}^{K} W_{k}^{*}} \\
V\left[M_{R}\right]=\frac{1}{\sum_{k=1}^{K} \frac{1}{V_{k}+\widehat{\tau}^{2}}}=\frac{1}{\sum_{k=1}^{K} W_{k}^{*}}
\end{array}
$$

固定効果モデルの重み $1 / V_{k}$ に対して, 変量効果モデルの重みは $W_{k}^{*}=1 /\left(V_{k}+\widehat{\tau}^{2}\right)$ と $\widehat{\tau}^{2}$ の分 だけ小さくなる $\widehat{\tau}^{2}=0$ の場合は, 固定効果モデルの場合と重みが等しくなり，結果は完全に等 しくなる . 分散を計算するときの分母の重みが少し小さくなるので, $V\left[M_{R}\right]$ は固定効果モデルの 分散 $V[M]$ と比べて大きくなり，これに伴い, 変量効果モデルでは固定効果に比べて統合効果が 有意になりにくくなり，また信頼区間の幅が広がる． $\widehat{\tau}^{2} に$ に比べて $V_{k}$ が相対的にかなり小さけれ ば, 各研究の重みは, 症例数に依存した分散 $V_{k}$ に関係なく, 全ての研究でほぼ等しくなる. 受動 喫煙データに変量効果モデルを適用すると, $\widehat{\tau}^{2}=0.00036$ と推定され, 対数リスク比を指標とし た統合効果は 0.217 となる $.95 \%$ 信頼区間は $0.119 \sim 0.315$ と少し広くなる.

実際のメタアナリシスでは変量効果モデルを拡張して, 効果の大きさと研究ごとに異なる対象 患者, 投与期間 , 投与量等の研究の特徵を示すべクトル $x_{k}$ の関係を固定効果によってモデル化す ることがある . このとき効果の大きさの推定值 $M_{K}$ の分布に $N\left(x_{k}^{T} \beta, V_{k}+\tau^{2}\right)$ を想定してメタ回 帰を行うことになる (Houwelingen et al. (2002)) . 本稿では数理的なメタアナリシスの説明は最 低限に留めるので, 詳細については, メタアナリシスの標準的な教科書を参照されたい (Sutton et al. (2000) , Whitehead (2002), 丹後 (2002)) . 


\section{3. 公表バイアスの分類}

メタアナリシスでは方法論上 , 公表バイアス (publication bias) という非常に重要なバイアス の影響を受ける可能性が高い，有意な結果が得られた研究と，乥うでない研究があったときにど ちらが公表されやすいかは自明なことである、研究論文では新規性が要求されるので, 有意な結 果の方が採択されやすくなる .これを公表バイアスとよぶ . Melander et al. (2003) は, スウェー デンにおける新薬の承認審査を行った経験から，医薬品の開発に関連した樣々な公表バイアスの 実状について報告しており，たいへん興味深い．したがって公表された研究のみを収集してメタ アナリシスを行なうと，結果は有意な方向に偏ることになる．

公表バイアスは狭義には, 出版のされ方に関するバイアスであるが , ここでは広義の意味で公 表バイアスを「研究の選択バイアス」と定義することにする . 公表バイアスについて , Egger and Smith (1998) の分類にしたがって紹介する (表 1).

表 1. 公表バイアスの分類 (Egger and Smith , 1998)
Publication bias（出版バイアス）
English language bias（英語バイアス）
Database bias（データベースバイアス）
Citation bias（引用バイアス）
Multiple publication bias（多重投稿バイアス）
Bias in provision of data（データ提供に関するバイアス）

•Publication bias (狭義の意味での出版バイアス)

Simes (1986) は進行卵巣癌の患者について単斉の化学療法と併用療法を比較した臨床研究のメ タアナリシスを, 結果が公表された研究のみで行なうと $p=0.004$ と有意になるが, International Cancer Research Data Bank に事前登録された研究について統合すると $p=0.17$ と有意にならな いことを報告した . また Easterbrook et al. (1991) が , 5 つの倫理委員会に研究計画が提出され た 1215 の臨床研究を評価した結果では, 有意な研究は光うでない研究に比べて, オッズ比で 3 倍 程度 (95\% CI 2.3～3.9) ，公表されやすかったことを示している.また Sterne et al. (2002) は 1998 年の Cochran のデータ (The Cocrane Database of Systematic Reviews (1998)) に基づい た 122 のメタアナリシスについて , 公表研究のみでメタアナリシスを行った場合の方が , より強 い介入効果の推定値が得られることを示している.研究の資金源によっても公表の確率は大きな 影響を受ける．国や第三者機関と比べて，製薬企業が資金提供者になる場合は，全体的に公表さ れにくい傾向にある (Davidson (1986)) . 製薬企業が資金提供者となる臨床研究では, 光れ以外 が提供者になる場合と比べて，新薬が有効であるという結果が多く報告されることが，非ステロ イド性抗炎症薬の例で報告されている（Rochon et al. (1994)) . また多施設臨床試験の方が，単 施設で実施された臨床試験より公表されやすいことも報告されている (Dickersin et al. (1992)) . Egger and Smith (1998) は, 公表バイアスの原因は, 有意な結果の方が受理されやすいというよ り，有意でない結果が出ると，研究者自身か投稿をあきらめてしまうためであると考察している．

・ English language bias (英語バイアス)

よい研究結果が出ると英文の一流䧱誌に投稿するが，あまりよい結果がでないと英文の杂隹誌は Jpn J Biomet Vol. 27, No. 2, 2006 
あきらめ，自国語で投稿する傾向がある .このため英文で公表された論文のみをメタアナリシス の対象にするとやはり結果が有意になりやすくなる .これを英語バイアスとよぶ . Egger et al. (1997) は，1985〜1994 年の間で，Medline で無作為化臨床試験を検索し，筆頭著者でマッチン グさせて，英語と独語の論文を比較した結果では，5\%水準で有意な結果が得られた試験の割合は 英語 : $63 \%$ に対して，独語では $35 \%$ しかなった（独語に対する英語の有意となった度数のオッ ズ比 $3.895 \%$ CI 1.3〜11.3) ことを報告している．

・Database bias (データベースバイアス)

Database bias（データベースバイアス）は，メタアナリシスで文献検索に用いるデータベース に偏りがあるために生じるバイアスである，例えば， Medline では，英語以外の言語で作成され た論文についても英語のインデックスを示しているが, 発展途上国の研究は $2 \%$ 含まれておら ず, 世界中の研究が網羅されているとは言い難い (Zielinski (1995)) .

・ Citation bias (引用バイアス)

Citation bias (引用バイアス) とは研究の結果によって引用のされ方が異なり，よい結果が出 ると多数引用され，多くの人に知られることになるが，これに対し結果がネガティブな場合あま り引用されず, 研究の存在自体も認知されないので, メタアナリシスの対象にされにくくなるバ イアスである . Helsinki heart study は, 虚血性心疾患の既往のない高脂血症患者に対して, 薬斉 によって LDL-コレステロールを低下させることによって , 心疾患の予防効果があることを証明し た歴史的な試験であるが, この研究は元々, 一次予防と二次予防について評価した研究であった . 一次予防の結果については New England Journal of Medicine という最も権威ある医薬ジャーナ ルに投稿され (Frick et al. (1987)) , 兴の結果は 450 回以上引用され, 多くの人の知るところに なった .これに対して二次予防については，結果自体は一次予防と同時期に判明したが，あまり よい結果ではなかったため，1993 年になるまで公表されなかった (Frick et al. (1993)) . ジャー ナルも Annals of Medicine と, New England Journal of Medicine と比べると, かなり流通が限 定されており，二次予防の結果については 17 回しか引用されてない (Egger and Smith (1998)). ・Multiple publication bias (多重投稿バイアス)

有意な結果の論文は，複数のジャーナルに投稿されたり，複数の学会で発表されやすい傾向に ある . 英語と自国語の両方で投稿したり, 多施設臨床試験の結果が , 全体と個別の施設の結果が

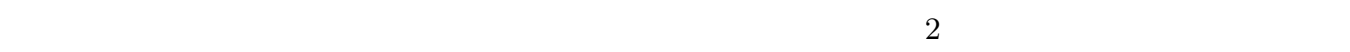
てメタアナリシスに 2 回含めてしまった例も存在する (Tramer et al. (1997)) . また , Melander et al. (2003) はスウェーデンで承認された大鬱病に対する選択的セロトニン再吸収阻害斉につい て, 臨床試験の結果と公表状況について検討を行った . ある薬斉については承認までに 15 のプラ セボ対照の無作為化臨床試験が行われた . 兴の結果 8 研究で有意な結果が得られた . しかしなが ら単独研究で公表された 11 の研究では 8 研究が有意となり, 公表されなかった 4 つの研究はいず れも有意でなかった . また 2 回公表されたものが 3 研究あったが , いずれも有意な研究ばかりで あった .

・ Bias in provision of data (データ提供に関するバイアス)

有意な結果が得られれば, 詳細な情報を含めて論文が投稿されるし，また他の研究者からメタ 
アナリシスを行なうため個別データの提供を要望されても，応じてくれる可能性が高いだろう . こ れに対し，結果がよくなければ, 論文投稿はあきらめて, 学会発表だけですまされてしまうかも しれない. 学会発表の要旨では, メタアナリシスを行なうのに必要な情報が得られない可能性が 高い . また , 結果がネガティブであれば個別データの提供も何らかの理由で拒否されるかもしれ ない.このように詳細なデータが入手可能な研究だけに限定してメタアナリシスを行なうと，や はりバイアスが生じてしまう.

\section{4. 公表バイアスに対する対処}

公表バイアスの統計学的な対処法としては既に多くの方法が提案されているが，ここでは大き く 3 種類に分類する.第一の方法は，視覚的な評価や，統計学的検定による公表バイアスの検出 である . 第二の方法は , 公表バイアスが存在するときの結論の頑健性を評価するために感度分析 を行うことである．第三の方法は，公表バイアスを調整した統合効果を推定するものである .

\section{1 公表バイアスの検出}

公表バイアスについて視覚的に評価するためのプロットがいくつか提案されているが, 最もよ く用いられるのが funnel プロットである (図 2 参照) .このプロットは各研究の効果の推定值を横 軸，縦軸に効果の推定精度の逆数をとったものである . funnel プロットの軸の選び方には例えば 各研究の症例数を縦軸にとることもあり，軸の選択肢と关れぞれの利点・欠点については Sterne and Egger (2001) がまとめている.オッズ比を評価指標とした場合，オッズ比を横軸に，オッズ 比の標準誤差の逆数をとることが多い.あるいはオッズ比の代わりに対数オッズ比をプロットす ることもある . オッズ比が 1 を下回るとき, 薬阁効果があることを想定すると, 症例数が大きく 精度がよい研究は, 上方でほぼ真值の近くに布置される．これに対し推定精度が悪い研究は, 下 方で真値を中心に広い範囲に分布するはずであるが , 公表バイアスがなければ左右対称にばらつ くはずである . 症例数が少なく，ネガティブな研究が隠される傾向がなければ，全体的には，漏 斗 (funnel) を逆さにしたような三角形になる .これに対し公表バイアスが存在すると，右下の

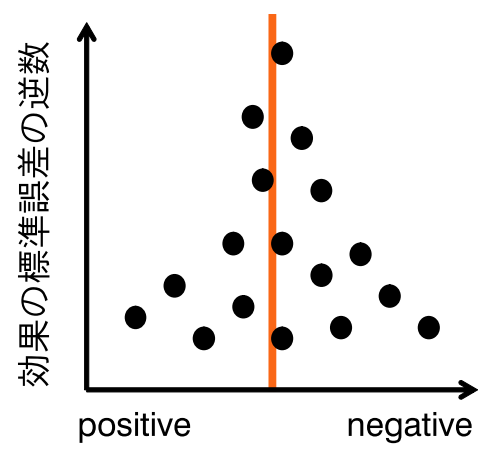

治療効果 $(\mathrm{M})$

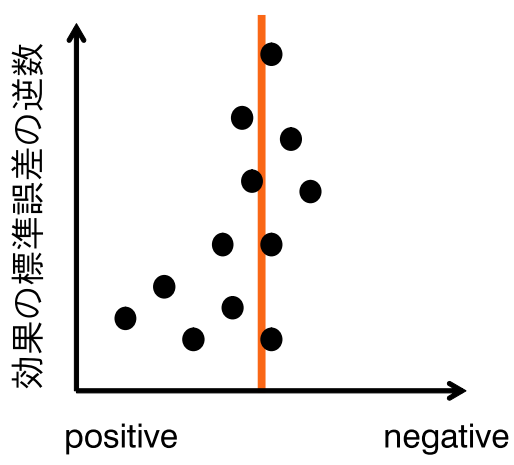

治療効果 $(\mathrm{M})$

公表バイアスあり

図 2. funnel プロットと公表バイアス 
部分が欠け左右非対称になる．

funnel プロットが最初に用いられたのは教育・心理学の分野である (Light and Pillemer (1984)) . 医学研究における公表バイアスの診断方法として funnel プロットの利用は Begg and Berlin (1988) の論文によって促進された . Rothstein et al. (2005) が Lancet などの 5 つの主要な医薬ジャーナ ルのメタアナリシスをレビューした結果, funnel プロットの利用が近年 , 劇的に増えていること が示されている . funnel プロットの利用は 1993〜1996 年は $5 \%$ 未満であつたが， 2001 年と 2002 年は $45 \%$ を越えていた . 更に Egger et al. (2003) は , 少なくとも一つ以上の未公表論文を含む， 58 のメタアナリシスで, 未公表研究を除いて funnel プロットを作成するとより左右非対称性か顕 著になることを報告している．

ただし funnel プロットによって公表バイアスか評価できる前提として, 精度が小さい研究から 大きな研究まである程度, 縦軸がばらつく必要がある. 観察研究のように, 症例数設計をしにく い場合は，精度は相対的に大きくばらつくはずであるが，無作為化臨床試験のように厳密な症例 数設計を行う場合は, 精度が研究間でばらつきにくいため, funnel プロットによる公表バイアス の視覚的検討は困難となる .

funnel プロットは左右対称であれば横軸と縦軸の相関は 0 になる . 公表バイアスが存在する場 合は, オッズ比が 1 を上回り, 症例数が少ない研究結果は公表されにくく，右下方部分が欠ける ので, funnel プロットは左右対称でなくなり，相関が生じる．したがって相関係数が 0 かを検定 し , 棄却されれば , 有意な公表バイアスが存在することになる . Begg and Mazumdar (1994) は， 効果の推定値の分散が 1 になるように基準化した上で, funnel プロットのケンドールの順位相関 係数を計算し，公表バイアスの有無を検定することを提案している . また Egger et al. (1997) は radial プロッ卜 (横軸 : 分散 $V$ の平方根, 縦軸 : 正規化検定等計量 $Z$ ) に基づいた , 公表バイアス の検定方法を提案している . しかしながら公表バイアスだけが funnel プロットの非対称性の理由 ではないことに注意しなければならない . 例えばEgger et al. (2003) はサンプルサイズが小さな 研究は, 大きな研究と比べて, 平均してデザインと解析の質が高くなく, 弚の結果として funnel プロットが非対称になる可能性を指摘している .

受動喫煙のメタアナリシスの funnel プロットを図 3 に示す. 横軸に対数リスク比, 縦軸に標準 誤差の逆数をとっている . 左下方の研究が欠けて左右非対称になっている. 受動喫煙の肺癌に対 するリスクが低いか・逆にリスクを下げる方向で , サンプルサイズが小さい場合は, 公表されに くくなるのが原因と考えられる.Begg and Mazumdar 法を適用し，順位相関係数が有意に 0 と 異なるか検定すると, $p=0.21$ と $5 \%$ 水準で有意とならないが, Egger 法では $p=0.024$ と有意に なり, 公表バイアスの影響が危惧される .

Sterne et al. (2001) は実際の 78 のメタアナリシスに対して Begg and Mazumdar 法と Egger 法を適用して，公表バイアスの存在を経験的に検討した . $10 \%$ の有意水準では，前者で有意になっ たのが $13 \%$ (10/78) に対して，後者では $27 \%$ (21/78) であった .ただし，Peters et al. (2006) はシミュレーションによって Egger 法は第一種の過誤確率が保たれないことを示している．

\section{2 結論の頑健性の評価（感度分析）}

英語では ‘failsafe N'あるいは‘file-drawer number' の解析とよばれる . 


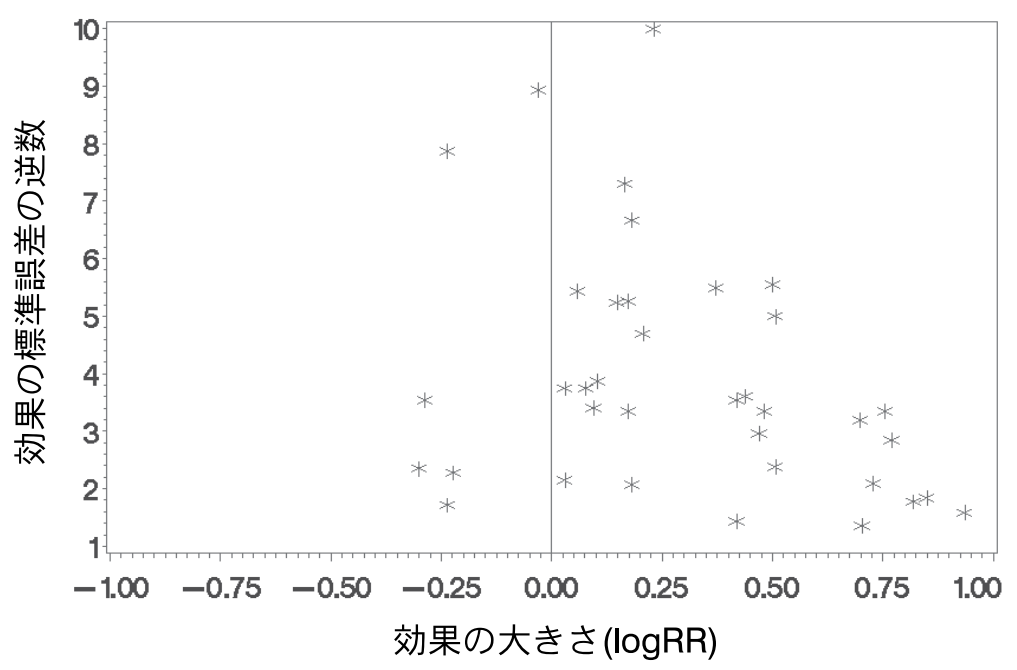

図 3. 受動契煙データの funnel プロット

メタアナリシスで有意な結果が得られても，ネガティブな研究が隠されたことによって有意に なった可能性がある．乥こで有意な結果を覆すのに必要なネガティブな論文数 (failsafe N) を推 定することによって , 検定結果の頑健性を評価する方法が提案されている . failsafe N が大きいと， 相当大きな公表バイアスがない限りは, 結論は覆らないわけで, 研究の収集に失敗があっても結 論は安全ということになる.あるいは研究者の引き出しの中に眠っているネガティブな研究を引っ 張り出す問題ということで‘file-drawer problem’とよばれる . Rosenthal (1979) はネガティブな 研究が , 片側検定で $p$ 值が 0 1 に一樣に分布する場合を想定した . 以下これを Rosenthal 法とよ ぶ.これに対し Iyengar and Greenhouse (1988) はネガティブな研究は有意にならないので, $p$ 值が有意水準 $\alpha \sim 1$ に一樣分布すると想定した .これが Iyengar and Greenhouse 法である . 有意 な結果を覆すのに必要な研究数が十分大きければ, 公表バイアスによって, 数研究程度が隠され ていたとしても有意という結論が覆ることはなく，検定結果の頑健性が示されることになる．

受動喫煙のメタアナリシスの 'failsafe N’を計算してみると , Rosenthal 法では 398 , Iyengar and Greenhouse 法では 103 研究であり，これはメタアナリシスの対象研究数 37 よりかなり大きいの で , 公表バイアスで隠れたネガティブな研究があったとしても，有意な関連があるという結論が 覆ることはなさ光うである .この他にも複数の $p$ 値を併合する Fisher 法で有意差か観察されなく なるのに必要な ‘failsafe N’を用いることも提案されている (Rothstein et al. (2005)) . 受動喫煙 のメタアナリシスではこの方法の 'failsafe N'は 79 研究となる .

\section{3 公表バイアスを調整した統合効果の推定}

検定結果の頑健性を評価するだけでなく，統合効果の推定值が公表バイアスによってどの程度 影響を受ける可能性があるか感度分析を行う必要がある .このため公表のメカニズムに何らかの 明示的なモデルをおいて , 公表バイアスを調整した統合効果の推定を行う.公表バイアスを調整 するには, 観察される研究の効果が, 公表される段階で選択される過程についてモデル化する必 
要がある .これを 'selection model'とよぶ .このモデルでは, 選択過程を規定するために 1 つ以 上のパラメータを持つ．一般的にこれらのパラメータの值は未知である．一つの方針は観察され た研究データを用いて , パラメータを推定することである . しかしながら , 'selection model' のパ ラメータをデータから推定することは困難であり，特に対象研究数が少ないときは不可能に近い．

これに対する一つの対処法は，公表バイアスの影響を調整した統合効果を計算するに当たって， 'selection model' のパラメータに特定の值を解析者自身が指定することである．これにより，統 合効果の推定に特定の大きさの公表バイアスが与える影響を評価することが可能になる .

Iyengar and Greenhouse (1988) はメタアナリシスの'selection model' を記述するために重み 関数を用いた.$M^{*}$ を研究の選択がない場合の効果の大きさを表す確率変数とし, 光の密度関数を $f\left(m^{*} \mid \theta\right)$ とする. $\theta$ か俲果の大きさを規定するパラメータである . 選択過程と観察された効果指 標 $M$ の尤度への関連を示すために非負の重み関数 $w\left(m^{*} \mid \omega\right)$ を導入する.$w\left(m^{*} \mid \omega\right)$ はパラメー 夕 $\omega$ によって , 効果指標 $M^{*}$ が与えられたときの相対的な公表のされやすさを規定する . このと き観察された効果指標 $M$ の重み付きの確率密度関数は

$$
g(m \mid \theta, \omega)=\frac{w(m \mid \omega) \cdot f(m \mid \theta)}{\int w(m \mid \omega) \cdot f(m \mid \theta) d m}
$$

となる.$w\left(m^{*} \mid \omega\right)$ が 1 でなければ, 選択過程のない確率密度関数 $f\left(m^{*} \mid \theta\right)$ と選択過程がある (9) 式の密度関数 $g(m \mid \theta, \omega)$ が異なり，この違いが公表バイアスをモデル化していることになる. 任意の重み関数について, 観察された研究の効果を用いて, $g(m \mid \theta, \omega)$ を $\theta \omega の$ 両方について 最大化することで, $\theta$ の最尤推定量を求めることができる . 大きく分けて 2 種類の重み関数がメ タアナリシスでは提案されている .一つは重みが片側 $p$ 值あるいは光れと等価であるが $Z$ 統計量 のみに依存するモデルである (Hedges (1992)， Iyengar and Greenhouse (1988)) .これに対し， 他方のモデルは観察された効果の大きさの推定値 $M$ と炎の分散 $V$ の別々の関数として重みが表 される (Copas (1999), Copas and Shi (2001)).

前者の最も単純なモデルは, $(10)$ 式のように $p$ 值を $j$ 個に区分して階段状の関数として, 重み を定義するものである．

$$
w(p)= \begin{cases}\omega_{1}, & \text { if } 0<p \leq a_{1}, \\ \omega_{i}, & \text { if } a_{i-1}<p \leq a_{i}, \\ \omega_{j}, & \text { if } a_{j-1}<p \leq 1\end{cases}
$$

研究 $k$ の効果 $M_{k}^{*}$ の分布に $N\left(\mu, V_{k}^{2}+\tau^{2}\right)$ の変量効果モデルを仮定して, 重み関数を

$$
w(p)= \begin{cases}\omega_{1}, & \text { if } 0.00<p \leq 0.05, \\ \omega_{2}, & \text { if } 0.05<p \leq 0.10, \\ \omega_{3}, & \text { if } 0.10<p \leq 0.50, \\ \omega_{4}, & \text { if } 0.50<p \leq 1.00\end{cases}
$$

と定義して受動喫煙データに適用すると, 対数リスク比に相当する統合効果の推定值は 0.13 と低 下する . また $95 \%$ の信頼区間は $-0.123 \sim 0.383$ となり，有意でなくなる . ただし，この例では $\omega$ 
左右対称になるように右から trim

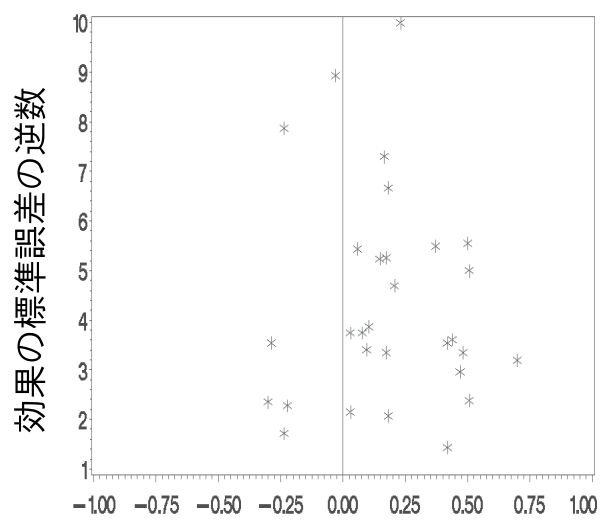

左右対称になるように左右に

fill

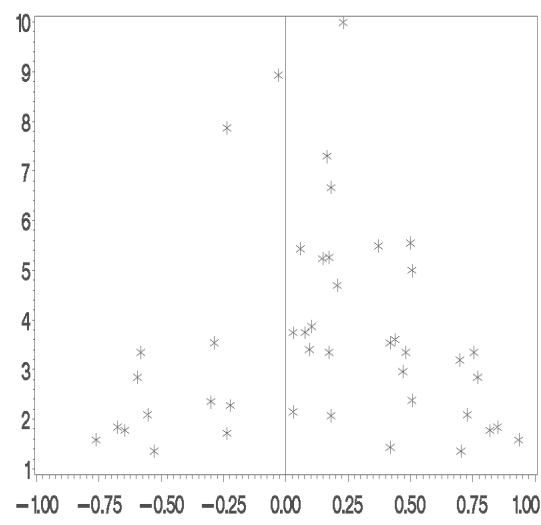

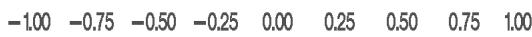

効果の大きさ $(\log R R)$

図 4. 受動喫煙データに対する trim and fill 法の適用結果

についても，推定の対象にしているので，推定が非常に不安定である . 実際重み $\omega$ の大きさは $p$ 值に対して単調には変化してなかった .'selection model'では，このように公表メカニズムを明 示的に想定する必要があるが, 現実には正確な公表メカニズムを特定するのは困難である .

これに対し Dual and Tweedie (2000) は特定の公表メカニズムを仮定する必要がない trim and fill 法を提案した . 前述のように公表バイアスが存在しなければ funnel プロットは左右対称にな る. そこで非対称なプロットを対称にするのに必要な研究数 (未公表論文数の推定值) を推定し， 兴の分だけ研究を削除 (trim) して, 弚の後削除した研究を funnel プロットに左右対称に配置 し (fill) , 人工的に左右対称にした後で効果の再推定を行う方法である (図 4 参照). Dual and Tweedie (2000) は負の二項分布に基づいて, 対称にするのに必要な研究数の推定法を提案して いる。

左右対称に近づけた後で, 効果の推定値が大きく変化するようであれば，公表バイアスの影響 を強く受けているし，光うでなければ公表バイアスの影響は小さいといえる. trim and fill 法は， MetaWin 等のメタアナリシスの専用ソフトウェアで利用可能であり，また汎用的な統計パッケー ジSASでもマクロが提供されている（松岡，浜田 (2003)). 受動喫煙データに trim and fill 法を 適用すると, 解析対象となった研究数 37 に対して, 左右対称にするために 7 つ研究が必要であ ると推定された . 右から効果の大きさ $(\log R R)$ の順に 7 つ研究を削除し ( $\operatorname{trim}$ 図 4 左), 左右 対称になるように統合効果を中心に左右に 7 つの研究を追加したところ (fill 図 4 右), 対数リス ク比は $0.174,95 \%$ の信頼区間は $0.077 \sim 0.270$ と少し小さくなった .

ただし Sterne (2000) はシミュレーション実験によって公表バイアスがなくても, trim and fill 法は誤差変動によって過剩に補填する傾向があることを示している . また Terrin et al. (2003) 研 究間で効果の異質性が存在すると, trim and fill 法の調整は不適切になることを報告している .

以上のように, 'selection model' の妥当性は, 仮定した重み関数すなわち公表メカニズムの妥 Jpn J Biomet Vol. 27, No. 2, 2006 


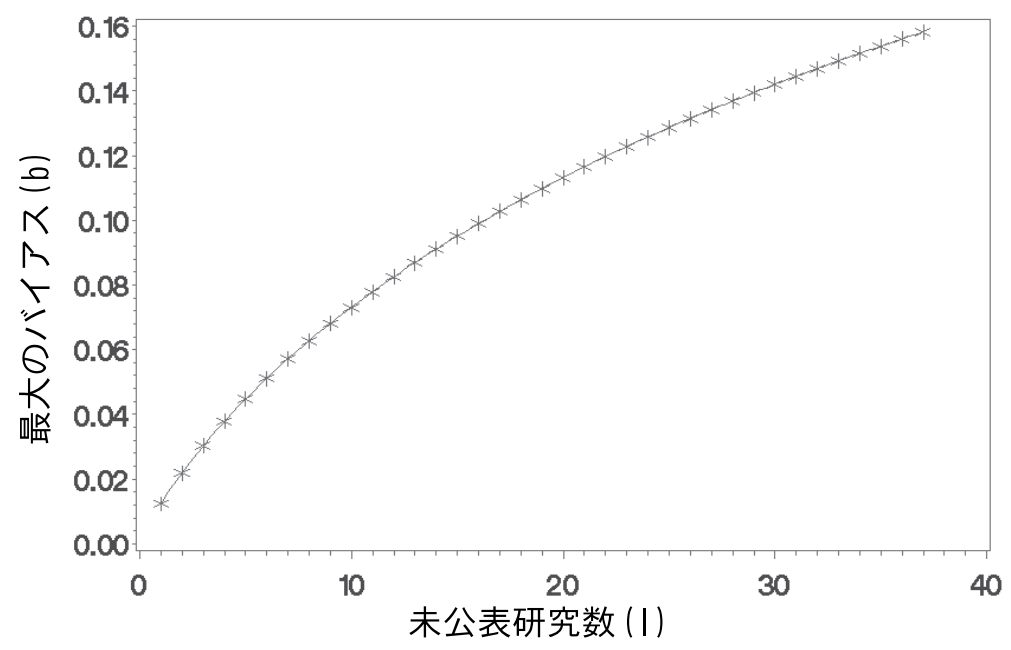

図 5. 未公表研究数と最大のバイアス

当性に依存するし, trim and fill 法は公表バイアス以外の理由でも左右非対称になったり, 未公表 研究数の推定が不安定になる等の問題がある . これに対し, Copas and Jackson (2004) はあらゆ る公表メカニズムの中で最悪の場合のバイアスの大きさを推定する方法を提案し , バイアスの最 大値の絶対値は，

$$
\mid \text { bias } \mid=\frac{n+l}{n} \phi\left\{\Phi^{-1}\left(\frac{n}{n+l}\right)\right\} \frac{\sum V_{k}^{-0.5}}{\sum V_{k}^{-1}}
$$

となることを示した .ここで $n$ は公表された研究数, $l$ は末公表の研究数,$V_{k}$ は観察された研究 の効果の分散の推定値， $\phi($ ) は標準正規分布の確率密度， $\Phi($ ) は標準正規分布の累積確率を表す. $l$ が大きく，また分散 $V$ が大きいときは，偏りは大きくなる . 未公表研究数をある範囲に想定 して, 乥れに対し, 統合効果が最悪でどの程度, 公表バイアスの影響を受けるか感度分析を行う 方法である。

受動喫煙の例で, 未公表研究数 $l$ を 1 から 37 まで変化させたときの, 対数リスク比のバイアス の最大值を図 5 に示す $. l=37$ で半分の研究が未公表として隠されている場合は, バイアスの大 きさは最大で 0.15 程度になる .これに対し固定効果モデルの対数リスク比は 0.215 であるので， バイアスを除くと対数リスク比は 0.065 となる.したがって公表バイアスの影響によって, 受動 喫煙は見かけ上肺癌のリスクをあげている可能性が大きい . これに対し,$l=5$ のときバイアスは 0.04 程度であり，未公表研究数がこの程度であれば, 公表バイアスの影響は大きくないといえる． ただしこの方法を適用するには未公表の論文数を想定する必要がある．

以上示してきたように, 公表バイアスの影響の統計学的検討については既に樣々な方法か提案 されているが, どれも一長一短があり, 公表されている研究のみをメタアナリシスの対象にした 場合は，結果の解釈はかなり慎重に行なわなければならない．また論文に記載されている情報の みでは, 樣々な解析を行うためには不十分なことが多く, 原著者に連絡をとって , 個別データを 入手するのか望ましい. 網羅的に研究を収集できなくても，結果に依存せずに全ての研究を等確 
表 2. 代表的なメタアナリシスのソフトウエアと公表バイアスに関連した機能

\begin{tabular}{|l|c|c|c|c|}
\hline & $\begin{array}{l}\text { CMA } \\
(2.0)\end{array}$ & $\begin{array}{l}\text { Stata } \\
(8.2)\end{array}$ & $\begin{array}{l}\text { RevMan } \\
(4.2)\end{array}$ & $\begin{array}{l}\text { MetaWin } \\
(2.0)\end{array}$ \\
\hline Funnel plot & $\bigcirc$ & $\bigcirc$ & $\bigcirc$ & 0 \\
\hline Begg and Mazumdar's rank correlation & $\bigcirc$ & $\bigcirc$ & & 0 \\
\hline Egger's regression & $\bigcirc$ & $\bigcirc$ & & 0 \\
\hline Failsafe N & $\bigcirc$ & & & $\bigcirc$ \\
\hline Duval and Tweedie's trim and fill & $\bigcirc$ & $\bigcirc$ & & $\bullet$ \\
\hline
\end{tabular}

CMA(Comprehensive Meta-Analysis): www.Meta-Analysis.com

Stata: www.Stata.com

RevMan: http://www.cochrane.org/software/download.htm

MetaWin: www.metawinsoft.com

率で入手できれば公表バイアスを避けることができる .このためには, 結果が出る前に , どの研 究をメタアナリシスの対象にするか宣言する，前向きメタアナリシスが有効である . 表 2 に代表 的なメタアナリシスのソフトウェアについての公表バイアスに関連した機能をまとめた . funnel プロットは 4 つのソフトウェアの全てで可能である . また CMA と MetaWin はほぼ同等の機能 を有している。

\section{5. 終わりに}

Feinstein (1995) はメタアナリシスのことを「21 世紀の統計学的錬金術」"Statistical alchemy for the 21st century”と皮肉った .これは，メタアナリシスに及ぼす樣々なバイアスの影響を色惧 してのものである . 無作為化臨床試験のメタアナリシスは科学的証拠能力が最も高い研究方法で あると考えられている．しかしメタアナリシスであれば , 全て科学的証拠能力が高いわけではな い. Malender et al. (2003) は, 医薬品の開発における樣々な公表バイアスが存在することを指 摘し，Evidence B(i)ased Medicine と皮肉った.(I) という私情を EBM に加えてしまえば，むし ろ，偏った根拠に基づいた医療に繋がってしまう．正しい方法論を用い，樣々なバイアスに対し て細心の注意をはらったメタアナリシスのみが EBM (Evidence Based Medicine) の重要な根拠 となり得る．

公表バイアスを根源的に防ぐためには, 臨床試験の登録制を実現し, 結果にかかわらず, 研究に関 する情報を入手することを可能にすることである . 2004 年 9 月の医学杂倠誌編集者国際委員会 (International Committee of Medical Journal Editors : ICMJE) の声明によると (http://www.icmje.org /clin_trial.pdf より入手可能), New England Journal of Medicine (米国), Lancet (英国) など の欧米の有名医学杂隹誌の編集者で構成されている国際委員会は, 臨床試験の規模や内容などを事 前に公表 (登録) しない限り，論文は掲載しない方針を明らかにしており，2005 年の 7 月以降， 
欧米，オーストラリアなどの 11 誌で実施されている . これにより，医学杂隹誌に投稿する研究の 事前登録制が始まった．我が国でも UMIN 臨床試験登録システム等 (2006 年 5 月 8 日現在，372 の臨床試験が登録) の運用が開始されている．

最終的に公表されない研究もデータベースには登録されることとなり, 未公表研究の数が明ら かになる．したがって，公表バイアスに対する根源的な対策が可能となる．しかし，臨床試験は 計画から結果報告までに 10 年近く掛かることも珍しくなく，この事前登録制度が浸透し，公表バ イアスを軽減するには少なくとも 10 年は必要であると思われ，まだ当分の間は，公表バイアスの 影響を統計学的に検討するために, 提案されている複数の方法を適用して, 結論の頑健性を検討 せざるをえないだろう .

\section{謝辞}

本研究は日本学術振興会の科学研究費 No. 16200022 の助成を得た . また貴重なコメントをいた だいた査読者及び編集者に心より感謝いたします．

\section{参考文献}

Begg, C.B. and Berlin, J.A. (1988). Publication bias: A problem in interpreting medical data. Journal of the Royal Statistical Society(Seris A) 151, 419-463.

Begg, C.B. and Mazumdar, M. (1994). Operating characteristic of a rank correlation test for publication bias. Biometrics 50, 1088-1101.

Chalmers, I. and Altman, D.G. (eds) (1995). Systematic Reviews. BMJ publishing Group.

折笠秀樹 (2003). 系統的レビューとメタアナリシスの実際. 日本循環器病予防学会誌 38-1, 34-42.

Copas, J.B. (1999). What works? Selectivity models and meta-amalysis. Journal of the Royal Statistical Association(Series A) 162, 95-109.

Copas, J.B. and Shi, J.Q. (2001). A sensitivity analysis for publication bias in systematic reviews. Statistical Methods in Medical Research 10, 251-265.

Copas, J. and Jackson, D. (2004). A bound for publication bias based on the fraction of unpublished studies. Biometrics 60, 146-153.

Davidson, R.A. (1986). Source of funding and outcome of clinical trials. Journal of General Internal Medicine. 1, 155-158.

DerSimonian, R. and Laird, N. (1986). Meta-analysis in clinical trials. Controlled Clinical trials 7, 177-188.

Dickersin, K., Min, Y.L. and Meinert, C.L. (1992). Factors influencing publication of research results. Follow-up of applications submitted to two institutional review boards. The Journal of the American Medical Association 267, 374-378. 
Duval, S. and Tweedie, R. (2000). A nonparametric "Trim and Fill" method of accounting for publication bias in meta-analysis. Journal of American Statistical Association 95, 89-98.

Early Breast Cancer Trialists Collaborative Group (1992). Sytematic treatment of early breast cancer by harmonal, cytotoxic, or immune therapy-133 randomized trials involving 31000 recurrences and 24000 deaths among 75000 women. Lancet 339, 71-85.

Easterbrook, P.J., Berlin, J.A., Gopalan, R. and Matthews, D.R. (1991). Publication bias in clinical research. Lancet 337, 867-872.

Egger, M., Zellweger-Zóhner, T., Schneider, M., Junker, C., Lengeler, C. and Antes, G. (1997). Language bias in randomised controlled trials published in English and German. Lancet 350, 326-329.

Egger, M., Smith, G.D., Schneider, M. and Minder, C. (1997). Bias in meta-analysis detected by a simple, graphical test. British Medical Journal 315, 629-634.

Egger, M. and Smith, G.D. (1998). Meta-analysis bias in location and selection of studies. British Medical Journal 316, 61-66.

Egger, M., Juni, P., Bartlett, C., Holenstein, F. and Sterne, J.A.C. (2003). How important are comprehensive literature searches and the assessment of trial quality in systematic review? Empirical study. Health Technology Assessment 7, 1-68.

Feinstein, A.R. (1995). Meta-analysis, statistical alchemy for the $21^{\text {st }}$ century. Journal of Clinical Epidemiology 48, 71-79.

Frick, M.H., Elo, O., Haapa, K., Heinonen, O.P., Heinsalmi, P. and Helo, P. (1987). Helsinki heart study: primary-prevention trial with gemfibrozil in middle-aged men with dyslipidemia. New England Journal of Medicine 317, 1237-1245.

Frick, M.H., Heinonen, O.P., Huttunen, J.K., Koskinen, P., Manttari, M. and Manninen, V. (1993). Efficacy of gemfibrozil in dyslipidaemic subjects with suspected heart disease. An ancillary study in the Helsinki heart study frame population. Annals of Medicine 25, 41-45.

Glass, G.V. (1976). Primary, secandory and meta-analysis of research. Educational Researcher 5, 3-8.

Hackshaw, A.K., Law, M.R. and Wald, N.J. (1997). The accumulated evidence on lung cancer and environmental tobacco smoke. British Medical Journal 315, 980-988.

Hedges, L.V. (1992). Modeling publication selection effects in meta-analysis. Statistical Science 7, 246-255.

Houwelingen, H.C., Arends, L.A. and Stijnen, T. (2002). Advanced methods in meta-analysis: multivariate approach and meta-regression. Statistics in Medicine 21, 589-624.

Iyengar, S. and Greenhouse, J.B. (1988). Selection models and the file drawer problem. Statistical Science 3, 109-135.

Jpn J Biomet Vol. 27, No. 2, 2006 
Lau, L., Ioannidis, P.A.J. and Schmid, C.H. (1998). Summing up evidence: one answer is not always enough. Lancet 351, 123-127.

Light, R. and Pillemer, D. (1984). Summing Up: The Science of Reviewing Research. Cambridge. 松岡伸篤, 浜田知久馬 (2003). メタ・アナリシスにおける公表バイアスの評価 trim-and-fill 法の SAS マクロの作成. 日本 SAS ユーザー会 2003 論文集, 379-388.

Melander, H., Ahlqvist-Rastad, J., Meijer, G. and Beermann, B. (2003). Evidence b(i)ased medicine-selective reporting from studies sponsored by pharmaceutical industry: review of studies in new drug applications. British Medical Journal 326, 1171-1173.

Peters, J.L., Sutton, A.J, Jones D.R, Abrams, K.R. and Rushton, L. (2006). Comparison of two methods to detect publication bias in meta-analysis. The Journal of the American Medical Association 295, 676-680.

Rochon, P.A., Gurwitz, J.H., Simms, R.W., Fortin, P.R., Felson, D.T., Minaker, K.L. and Chalmers, T.C. (1994). A study of manufacturer-supported trials of nonsteroidal antiinflammatory drugs in the treatment of arthritis. Archives of Internal Medicine 154, 157-163.

Rosenthal, R. (1979). The file drawer problem and tolerance for null results. Psychological Bulletin 86, 638-641.

Rothstein, H.R., Sutton, A.J. and Borenstein, M. (2005). Publication Bias in Meta-analysis. John Wiley and Sons.

Sackett, D.L., Straus, S., Richardson, S., Rosenberg, W. and Haynes, R.B. (2000). EvidenceBased Medicine: How to Practice and Teach EBM (2nd edn). Churchill Livingstone.

Simes, R.J. (1986). Publication bias: The case for an international registry of clinical trials. Journal of Clinical Oncology 4, 1529-1541.

Simon, R. (1987a). Overview of randomized clinical trials. Cancer Treatment Reports 71, 3-5.

Simon, R. (1987b). The role of overviews in cancer therapeutics. Statistics in Medicine 6, 389-393.

Sterne, J.A.C. (2000). High false positive rate for trim and fill method. Electronic response to Sutton et al. (2000) British Medical Journal website only: http://www.bmj.com/cgi/eletters/320/7249/1574\#E1

Sterne, J.A.C. and Egger, M. (2001). Funnel plots for detecting bias in meta-analysis: guidelines on choice of axis. Journal of Clinical Epidemiology 54, 1046-1055.

Sterne, J.A.C., Gavaghan, D. and Egger, M. (2001). Piblication and related bias in meta-analysis: Power of statistical tests and prevalence in the literature. Journal of Clinical Epidemiology 53, 1119-1129. 
Sterne, J.A.C., Juni, P., Schulz, K.F., Altman, D.G., Bartlett, C. and Egger, M. (2002). Statistical methods for assessing the influence of study characteristics on treatment effects in 'meta-epidemiological' research. Statistics in Medicine 21, 1513-1524.

Sutton, A.J., Abrams, K.R., Jones, D.R. Sheldon, T.A. and Song, F. (2000). Methods for MetaAnalysis in Medical Research. John Wiley and Sons.

丹後俊郎 (2002).メタ・アナリシス入門. 朝倉書店.

The American Society of Clinical Oncology (1997). Clinical practice guidelines for the treatment of unresectable non-small-cell lung cancer. Journal of Clinical Oncology 15, 2996-3018.

The Cocrane Database of Systematic Reviews (1998). The Cochran Library. Update Software. Oxford.

Terrin, N., Schmid, C.H., Lau, J. and Olkin, I. (2003). Adjusting for publication bias in the presence of heterogeneity. Statistics in Medicine 22, 2113-2126.

津谷喜一郎 (1997). コクラン共同計画とシステマティック・リビュー. 薬理と治療 25, 11-24.

Tramer M.R., Reynolds D.J.M., Moore R.A. and McQuay H.J. (1997). Impact of covert duplicate publication on meta-analysis: a case study. British Medical Journal 315, 635-640.

Whitehead, A. (2002). Meta-analysis of Controlled Clinical Trials. John Wiley and Sons.

Zielinski, C. (1995). New equities of information in an electronic age. British Medical Journal 311, 1480-1481. 